\title{
Intentional Ecology: Integrating environmental expertise through a focus on values, care and advocacy
}

\author{
Alexandra R. Knight (1) ${ }^{1 凶} \&$ Catherine Allan (iD ${ }^{1}$
}

As the significance of environmental degradation for humanity becomes apparent, the challenge of developing expertise in integrating science, advocacy and implementation has been acknowledged. Addressing recent and ongoing global challenges including mass extinction, climate change, disease and threats to food, water and power security requires employment of evidence-based science in multi-faceted approaches. Ensuring the mobilisation of new knowledge in practice, both in policy and on-ground actions, takes many researchers into the realm of advocacy, where facts and values become equally important. In the nexus between research and practice, guidance in integrating approaches is required. Drawing on the fields of conservation biology, systems theory and feminist science, this paper offers a new conceptual framework to guide researchers and professionals; one that supports practice by encouraging action and advocacy. The framework, intentional ecology, requires examination of ethics and acknowledgement of the human endeavour that supports curiosity and care in research. Intention is the key concept here as it incorporates beliefs, choice and actions. A case study of the application of intentional ecology to research into, and conservation of, a small, threatened amphibian, Sloane's Froglet, in South Eastern Australia is provided. Many environmental issues are complex and it is difficult to find a single point to address. While acknowledging that complexity, intentional ecology provides an ethical basis and imperative to act. In so doing intentional ecology enables early, applied and relevant integrated action and reflexive and dynamic approaches to implementation.

\footnotetext{
${ }^{1}$ Institute for Land, Water and Society, Charles Sturt University, Albury, NSW, Australia. ${ }^{\varpi_{e}}$ mail: aknight@csu.edu.au
} 


\section{Introduction}

he significance of environmental degradation to humanity is becoming increasingly apparent as we react and respond to pollution, fire catastrophes, loss of biological diversity, disease and insecurity of water, food and energy. Transformative learning and action are called upon by those aiming for sustainability (e.g. Fazey et al., 2018). A sustainable world could be considered both rich and complex, incorporating diversity in the more-than-human world (genes, species, ecosystems) and the human world (cultures, relationships, ethical standards, values and beliefs) as well as (inter)connections across space and time, and the space between them.

Environmental scientists and practitioners recognise that changes that can occur by applying knowledge developed though ecological research are vital and urgent (Ceballos et al., 2015; Woinarski et al., 2015). For those working with threatened species, practicing in fields such as amphibian conservation, the immediacy of threats and ubiquity of decline provide a moral imperative to not only generate useful new knowledge, but also to act. Ensuring new knowledge is used, and that practice is changed, is complex and often requires advocacy. Advocacy involves speaking on behalf of something, acting on values and beliefs; as such, advocative claims invoke questions about the right actions to be taken (van Herten and Runhaar, 2013). Scientists who are advocates articulate research findings along with beliefs about how those findings could or should be applied. Advocacy is driven by specialist knowledge, but also care, which places specialist knowledge in the political realm of making choices. We propose that advocacy is a practical operational space for overcoming the fragmentation of expertise identified by Bammer et al. (2020).

The political context of scientific work and policy development is well recognised (Turnhout, 2018). Yet, while some consider that questioning whether scientists should be advocates is passé (Wittemyer et al., 2018) there is still debate among researchers regarding the credibility of being involved in advocacy (Garrard et al., 2016; Nelson and Vucetich, 2009; Reiners et al., 2013). There is little guidance available on how to adequately address the practical ethical issues associated with promoting researchers' values along with their research results (Minteer and Collins, 2008; Pooley et al., 2014). Understanding how to effect the movement of conservation knowledge from research into practice is growing, with input from the fields of translational ecology (Enquist et al., 2017) and action-oriented research (Fazey et al., 2018). Translational ecology recognises the social context of ecological research, and the importance of the complex interdisciplinary context for decision-making and action (Enquist et al., 2017). Action-oriented research brings immediacy to research in a collaborative and often local approach, and is considered by some to be essential for the transformational change needed to underpin sustainability (Fazey et al., 2018).

Two main issues persist: how to combine scientific rigour with human values, ethics and advocacy, and how best to enable early, applied and relevant knowledge exchange that leads to effective practices (through change or maintenance of existing practices). This paper provides a framework that addresses these issues. We first discuss the importance of values and ethics in ecological research, challenging often implicit assumptions about researchers' independence from their subjects and revealing the relationships among scientists' intentions, values and actions. We then present a conceptual framework for 'intentional ecology' which allows and enables integrated, informed, reflective and potentially transformative action which can support a rich and complex future. Finally, we provide a case study of the transdisciplinary and interdisciplinary (Bammer et al., 2020; Pooley et al., 2014) research and advocacy efforts used to benefit a little known and rare Australian amphibian, Sloane's Froglet (Littlejohn, 1958), describing our approach, actions and challenges. Through this case we illustrate how using the conceptual framework could enable researchers to move beyond providing conservation knowledge advice into integrated and active management.

\section{Values, ethics and advocacy}

There is growing recognition that research is value-based, yet often values are implicit and unstated. Thomas Lovejoy, while exploring global amphibian decline, promotes the need for scientists to be activists: "When does a researcher stop being a scientist and begin being an advocate? When doing science, I work and think like a scientist. But I am also a citizen, and it is not only correct but, in my view, also is incumbent upon us as scientistcitizens to state what we think the implications of science are. If we don't, then, who will?" (Lovejoy, 2009, p. xiii). Similarly, revered Australian scientist and founding member of the Wentworth Group of Concerned Scientists, Peter Cullen (see, for example, Cullen, 2004), noted that "beneficial outcomes are unlikely unless science can be actively engaged in the development and assessment of appropriate policies" (Cullen, 2006, p. 1) and also recognised that "scientists commonly hold strong values about desirable outcomes" (Cullen, 2006, p. 10).

For both Lovejoy and Cullen, above, 'advocacy' is seen as an important component of being a scientist. Advocative claims rest on both 'facts' and 'values' (van Herten and Runhaar, 2013, p. 1006) and knowledge itself is used strategically according to the values of different interest groups, as people advocate for things they value. Different values and beliefs thus "influence the flow and transformation of knowledge" (Fazey et al., 2013, p. 24).

Discussion of values and beliefs in this context reflects discourses in contemporary philosophy of science; that science and the research process are neither value-free (e.g. Latour, 1998; Longino, 1987), nor free of the societal context in which they are undertaken (Nowotny et al., 2001). Research focus is selective and may be driven by many factors, including the desire to gain funds (Turnhout, 2018). Until recently most scientists have not been involved in decision-making for policy or management, a position derived from the philosophy of positivism, where the role of scientists is understood as being to provide 'objective' information (Lach et al., 2003). The positivist paradigm developed alongside the idea of science itself in the Enlightenment, and hence has a long and strong tradition (Nowotny et al., 2001). In the context of positivism science is perceived as both certain and detached (Latour, 1998).

Many scientists fear that their credibility will suffer if they lose their detachment and participate in advocacy (Lach et al., 2003). Some scientists, however, contend that an environmental ethic that allows and enables advocacy informs and is foundational to their work. For instance, the discipline of conservation biology provides an explicit motivation to not only undertake applied research (Meine et al., 2006) but also overtly expresses the need for an ethical approach. In his seminal article on the nature of Conservation Biology, the discipline which addresses the application of science to environmental and conservation problems, Soulé (1985) states that "ethical norms are a genuine part of conservation biology, as they are in all mission- or crisis-oriented disciplines" (p. 727). While ethical values that inform purposeful research are expressed by many ecologists (see for instance Society for Conservation Biology, 2020), little guidance is provided for researchers in reflecting how their values might impact upon their work or its outcomes. Developing expertise in advocacy and implementation requires an examination of ethics. 
We consider that applied ecological research has changed and developed in response to the complexity of the social ecological systems of which it is part, and can usefully incorporate other theoretical perspectives that allow and enable rigorous interdisciplinary research, advocacy, knowledge exchange and care. We call this advancement, which responds both to calls for advocacy and to the need for better knowledge exchange practices, intentional ecology, and explain how this framework was developed below.

\section{Intention is important in enabling advocacy and action}

Intention is the key concept here. Intention enables both knowledge exchange and advocacy. Intention moves into the realms of action and choice and builds on ethical foundations, values and beliefs. Intent is about purposeful action, taking researchers and practitioners beyond the concept of value-free science. Intent has to do with morals (what ought and ought not be), beliefs (what is held to be true) and actions. Because intent is value-laden it leads to considerations of ethics. Intention infers selectivity (Turnhout, 2018), decision-making and choice based on both internally held values and a person's resultant ethical position while acknowledging complex external filters such as availability of funding and current policy directions. Intention, then, can be linked with aims and purposes, meanings and significance (von Wright, 1971), including the intention of reseach.

Reflecting upon intention is a useful activity for ecologists who integrate their work with environmental managers and who act and advocate to bring their research to life in practice. Reflection on intention allows them to question and expose the purpose and values they bring to their work, and shapes approaches, methods, and outcomes. This reflection and questioning contextualises the research and provides opportunity for research practice and application to be more clearly understood. Exposing the intention of research provides opportunity for researchers to work within their discipline in a way that exhibits ethical congruence with their values and beliefs, and may lead to the desire to advocate for particular use of their research findings. Reflection on intention also exposes differing and shared conceptual foundations and values, and that exposure in turn can help build understanding and expertise, and potentially a shared reflexivity among collaborators (Borie et al., 2020), whether they be researchers, managers or citizens. In the next section we describe our intentional ecology framework.

\section{Intentional ecology: A new way of conceptualising ecologically related research and practice}

Intentional ecology involves building careful scientific research with the explicit intention of using that information to foster change within a transdisciplinary framework. We use the term transdisciplinary here in the sense of embracing learning and practice from differing disciplines that enables engagement with policy and management. Transdisciplinarity recognises a focus on complex real-world problems. Integral to this is the notion that non-academics will be involved in research processes (Zscheischler and Rogga, 2015).

We constructed an intentional ecology conceptual framework composed of both theoretical foundations and actions that the foundations would enable (Fig. 1). The framework emerged simultaneously and iteratively while applying our scientific research and community actions to benefit a small, threatened amphibian in southern Australia (the details of this case study are discussed below).

Four factors constitute intentional ecology: reflecting upon and being explicit about our boundaries; using multiple approaches (for instance, different methods based on both inductive and deductive reasoning); advocating and acting for improvement based on values; and, applying care to humans, the more-than human world, the biosphere and the interrelationships among them. Developing the intentional ecology framework required insight from theoretical perspectives of conservation biologists, systems thinking, and feminist science. Because intentional ecology is dynamic, we also gained insight from theories of knowledge exchange, co-production, and adaptive management (Fig. 1).

\section{Systems theory offers tools for Intentional Ecology}

Systems theorists provide environmental researchers and on ground practitioners with motivation and guidance for further exploring values and ethics. For example, Midgley (2003, p. 89) demands that scientists consider their values and in so doing strengthen their work, and provides three tools within an intervention science framework with which to undertake researchboundary critique, multiple approaches and methods, and action for improvement. These three tools are useful for researchers who see themselves as deeply seated and participating in applied research, such as amphibian ecologists who are exhorted to become advocates and "state what we think the implications of science are" (Lovejoy, 2009).

Feminist theory provides a foundation for Intentional Ecology Feminist science (e.g. Longino, 1987; Subramaniam, 2009) and contemporary feminist theory (e.g. Levy, 2013; Stephens, 2012) provide critiques of the objective nature of science. The need to reflect and to act can be based upon an ethic that embraces human's connection with the natural and material world and the realisation of the interrelationship between human health and the natural environment (e.g. Levy, 2013, p. 216). The scientist is more than a passive observer, being an integral part of the world he or she observes. Levy (2013) provides examples of scholars who bridge the gap between social and biophysical sciences and who

inspire other feminists to consider deepening their scientific literacy. This is important because feminist theorists could mobilise scientific findings, particularly those that point to our interconnectedness, to put forward a case for an ethic of care and love towards the environment and toward other bodies (Levy, 2013, p. 19).

The quote from Levy is, in other words, another call to action based on values. Where Midgley (2003) invokes purposeful action, Levy (2013) calls for the mobilisation of scientific findings. Levy goes beyond a call for action, to a case for an ethic of care and love, a call to our heart.

The call for care, a fourth tool for the intentional ecologists, is well-established in environmental philosophy as well as environmental activism, and is some cases is based upon an appeal to emotions which may reside alongside science. Hay (2008) calls this the 'ecological impulse', similar to Wilson's (1984) biophilia and considers the emotional response a "powerful policy informant" (p. 7). 'Care' was also the context of Aldo Leopold's (1949) influential and inspirational work which encourages humans to consider their responsibility to the natural world. This emotional and ethical response can ensure that the actions of researchers and their collaborators are based on care for the biosphere, nonhumans and humans.

Intentional ecology allows and enables ecologists to combine reflection on practice boundaries with taking multiple approaches, acting for improvement and applying care to the natural world. Intentional ecology requires awareness and articulation of the boundaries to the research undertaken. Exposing intentions 


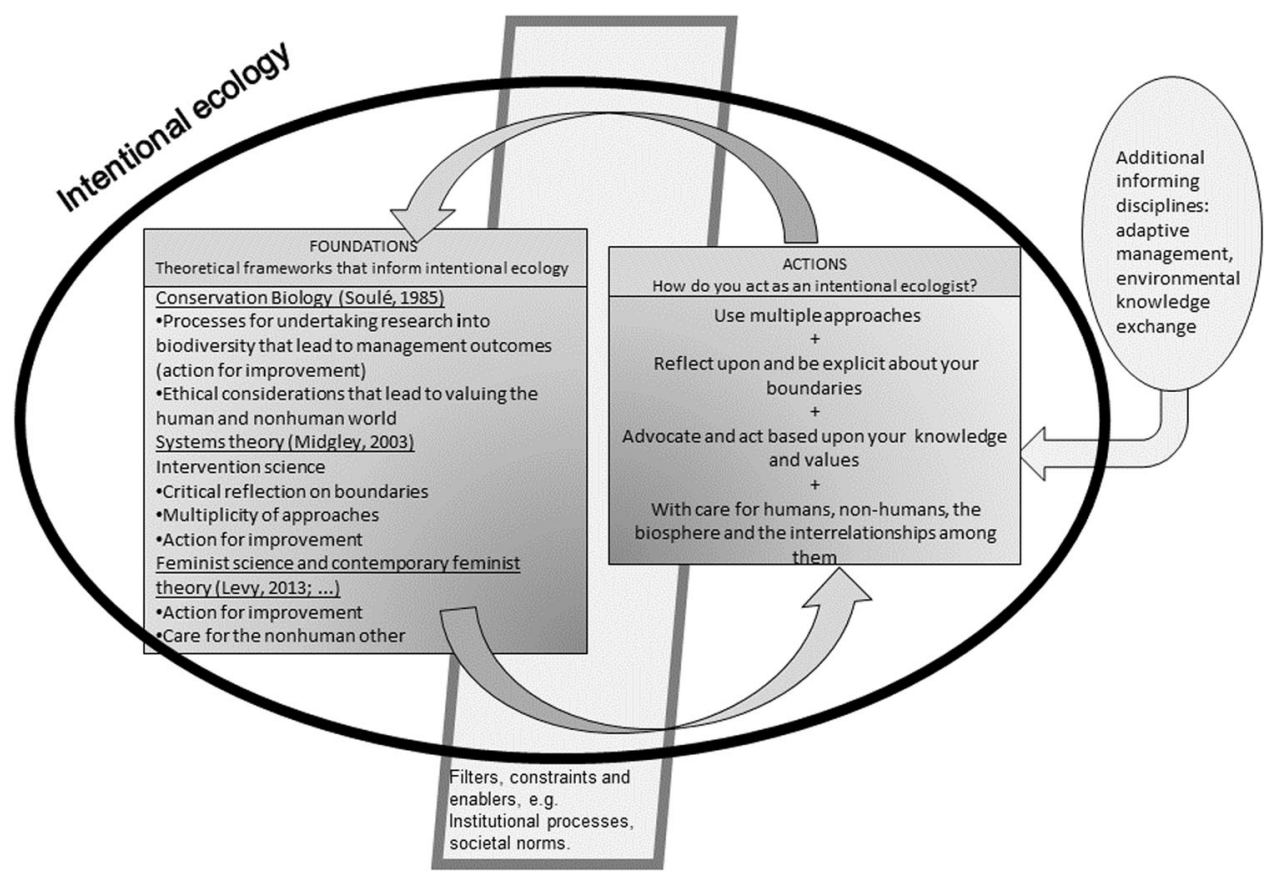

Fig. 1 A schematic of intentional ecology. The foundations of intentional ecology and the actions that are integral to intentional ecology are indicated in boxes. Informing disciplines contributing to intentional ecology are depicted in a circle. External filters that influence the relationship between foundations and actions are indicated in a box. The arrows indicate the interrelationships between foundations, actions, filters, and informing disciplines.

which motivate action, whether the action is to influence practice or to undertake applied research, can support a rich, complex society that connects action with science AND reflection. And exploration of shared intentions provides a frame for bringing together fragmented expertise.

The intentional ecology framework acknowledges that environmental research and practice are generally filtered, enabled and constrained by political will, institutional and normative processes, research fashions and dominant paradigms. The filtering processes might also be considered to be the ideologies or "macrosocial and economic forces" (p. 92) that Midgley (2003) describes when he asks us to make explicit the value judgements that we use to decide upon our research rather than keeping these values marginal to science. Other fields, specifically those of knowledge exchange (e.g. Fazey et al., 2013) and adaptive management (Allan, 2009; Holling, 1978) offer important insights for the framing and use of new information, highlighting the importance of learning through acting.

\section{Sloane's froglet-an example of the application of the intentional ecology framework}

For the ecologist who is using rigorous methods and analysis of their data, who embraces the need to see their knowledge used, and is comfortable with the ethical considerations, the problem remains; how to effect knowledge mobilisation and utilisation?

In the following sections we describe how the application of intentional ecology, including the consideration of values, ethics and knowledge exchange processes, impacted upon our research and practice into the little-known and rare Sloane's Froglet; how it improved our understanding of the social-ecological context of both research and practice; and, how this provided a pathway for effective knowledge mobilisation without compromising scientific rigour.

We commenced research into Sloane's Froglets' ecology in 2009 , shortly after its listing as a threatened species. With very little known about the species, the first questions addressed were those of its current distribution (Knight, 2013a) and detection. It

\section{Sloane's Froglet}

Sloane's Froglet (Crinia sloanei, Littlejohn, 1958) is a small (15-20 mm long) ground-dwelling froglet occurring in south-eastern Australia (Knight, 2013a) and a member of the Myobatrachidae family which contains $\sim 82$ small to medium size ground-dwelling frogs species distributed only within the Australian region (Anstis, 2013). Sloane's Froglet was listed as a threatened species in the state of New South Wales, Australia in 2008 (Hughes, 2008) and following our research and advocacy was listed as nationally endangered in Australia in 2019 (Department of Agriculture, Water and the Environment, 2019).

Many species of the Crinia genus are relatively well known; for instance there is considerable research into the sympatric Crinia signifera (e.g. Lauck, 2005; Lemckert, 2001; Littlejohn, 1964; Mac Nally, 1979) and into the similarly threatened Crinia tinnula (e.g. Letnic and Fox, 1997, Meyer et al., 2004; Simpkins et al., 2014). There is, however, very little known about Sloane's Froglet with the only published research material prior to our work commencing available in the original description (Littlejohn, 1958), a description following Littlejohn in Anstis (2002) and Anstis (2013) and a brief mention in Read et al. (2001). Hero et al. (2006) in their overview of the conservation status of Australian frogs list it as DD-"data deficient" (p. 318).

became evident that an extant population of Sloane's Froglet occurred within areas that were being rapidly developed. These areas were being changed from rural or rural residential to suburban landscapes, with associated changes in wetland number, spatial arrangement, connectivity, and water flow and permeability. Within this complex social ecological context, the intent of the research became not only to generate sound ecological knowledge of the species, but also to raise awareness, take action, initiate management practices and develop and implement an ethical approach that involved care for Sloane's Froglet and the biosphere. The context for conserving Sloane's Froglet necessitated methodological pluralism and a structured transdisciplinary approach. 
In the following sections we describe how the four actions (see Fig. 1) of an intentional ecologist were incorporated into our research, advocacy and action. Note that we present the actions with numbers below as an explanatory aid, but the actions below are not a linear progression- rather the actions must operate in parallel, with multiple iterations and adaptive adjustments.

\section{Intentional Ecology Action 1: use multiple approaches}

We used well-established ecological methods to research the distribution (Knight, 2013a) and habitat of Sloane's Froglet to obtain fundamental information that would be directly and immediately applicable to management (Knight, 2014). We aimed to construct a picture as close to a perceived objective reality as possible within specific acceptable research boundaries. In line with this approach, we developed hypotheses and predictions regarding the wetland and microscale habitat (Gorman and Haas, 2011; Popescu et al., 2013) of the species as well as undertaking modelling that allowed for multiple competing hypotheses and inference, designed a method for field research, gathered and analysed data and presented it for discussion. Untransformed data were used in publications for public consumption so that the information could be presented in a way suitable for environmental managers to interpret (Knight, 2014).

To support the critical need to share the new knowledge being learnt about the species, we explored managers' insights into knowledge exchange (Fazey et al., 2013), undertaking interviews with water and natural resource managers in the region and using an inductive approach to analysis (Knight, 2015). Our exploration involved developing a cohesive story from very complex data. This added significantly to an understanding of the nature of possible methodological plurality, as participants considered knowledge built from experience and anecdotal evidence (Raymond et al., 2010), and cultural knowledge as important approaches to understanding. Participants indicated that continual learning was an important consideration. They also suggested that methods of knowledge production should be inclusive of co-production (Schuttenberg and Guth, 2015) and collaboration, and that these were important considerations and frameworks for environmental research and management.

Using a methodologically plural approach, and completing a transdisciplinary body of research revealed the complexity in undertaking ecological research that could be quickly and willingly applied to benefit Sloane's Froglet. It also provided insight into the processes that may enable action for this species.

\section{Intentional Ecology Action 2: Reflect upon and be explicit about your boundaries}

We gathered data on calling adult male Sloane's Froglets only in winter (peak breeding season) within a study region of southern Australia (Knight, 2013a, 2015). The research has provided foundational knowledge of the species within a particular region and season, and knowledge of female and tadpole Sloane's Froglets may be inferred from the knowledge developed about males, but the knowledge on females and tadpoles is not explicitly developed. There were sound scientific reasons for these limitations to or boundaries around the research, including the lack of knowledge of extant populations of Sloane's Froglets in other parts of Australia and the difficulty in locating female Froglets and in identifying tadpoles (Anstis, 2013). The knowledge developed within these boundaries may be applied to a more holistic management approach for waterbodies within the region and also inform future research and practice in other regions should Sloane's Froglet be located elsewhere.

Other boundaries were delineated by choice. For example, we intentionally chose to research habitat rather than chytridiomycosis (a fungal disease). The boundary that we placed around the research here was informed by Gardner et al. (2007) who strongly argue for the need for habitat studies; and in consideration that there have been few if any recorded frog mortalities due to chytridiomycosis in the kind of environment (hot and low elevations) the study region sits within. We also chose habitat over behaviour. The choice of studying habitat was informed through the persuasion of a dominant paradigm in conservation biology and environmental practice, that humans are in a position where they can protect, restore and reconnect habitat and the associated funding availability for habitat research.

As with the choices made when studying the ecology of Sloane's Froglet, boundaries are also evident in the social research undertaken. The case study material reflected the state of advocacy and knowledge exchange in regional south eastern Australia regarding threatened species and water management.

\section{Intentional Ecology Action 3: Advocacy and action for Sloane's Froglet based upon knowledge and values}

During and following the scientific data collection and analysis we provided presentations to several local community groups and forums, seven Landcare groups, individual stakeholders and landholders, non-government conservation organisations and government officials from state and federal environmental agencies. We provided media releases that were taken up by local newspapers (e.g. Partenza, 2010). The project received additional public interest after author Knight spoke on national radio. Two regional non-government natural resource management organisations, the Albury Conservation Company and Corowa District Landcare, became actively involved in supporting actions to benefit Sloane's Froglet and we provided ongoing project updates to them. We also developed information sheets (Knight, 2013b) and brochures (Knight, 2014) based on early analysis of distribution and habitat data which were made publicly available on the internet, while the research was underway. We facilitated an initial stakeholder meeting which discussed management options with key landholders and council staff. We provided frog identification training days for school children and members of the public and wetland rehabilitation training for council, golf course and other land managers.

Rich knowledge and experience of interviewed environmental practitioners provided knowledge of how advocacy and action can be undertaken and information about what was needed, so the research iteratively supported the approach of ensuring knowledge becomes utilised (Knight, 2015). Practitioners provided insight into how knowledge might be shared, mobilised and used and therefore how as researchers we could 'act for improvement'.

Advocacy for Sloane's Froglet and collaboration with environmental practitioners when undertaking the research have led to beneficial actions being undertaken for the species in particular situations and locations (Johnston, 2017). For instance, one important breeding wetland was saved from destruction associated with the development of essential infrastructure (digging in a new sewerage line) after the local engineer was informed of the importance of the wetland well before thesis publication. Resistance to protecting Sloane's Froglet does unfortunately still occur, most probably because Sloane's Froglet inhabits land planned to be used for profitable housing developments. Resistance in this case has included organisations and developers attempting to undermine the credibility of the scientists involved by contracting ecological consultants to explore the 'veracity' of the thesis postexamination. 


\section{Intentional Ecology Action 4: With care for humans, non- humans, the biosphere and the interrelationships among them}

Many ecological researchers indubitably care about the organism or process that they are studying. It is possible to become as close to your research as to any friend who leads you on a great adventure and broadens your knowledge and understanding, whose life you share and wellbeing you worry about. Sloane's Froglets were and are intriguing, a reasonable reaction for a scientist as science is based on curiosity (Marder, 2011). A willingness to ask the next question, to observe and wonder, is fundamental to the scientific process. We believe it is this curiosity and care that motivated us to continue working in arduous, very cold conditions and ensure that our methods and sample sizes were adequate.

Many researchers feel a heavy burden of care and responsibility. Care can be considered a strength and a motivating force. In advocating for the protection of Sloane's Froglet we expressed our delight in its beauty, its tiny nature, its seeming courage as it chirps and breeds in the middle of cold wet winters and in so doing provided an expression of Hay's (2008) ecological impulse and Wilson's (1984) biophilia.

\section{Discussion}

We applied the intentional ecology framework in the Sloane's Froglet case to transcend single-species ecological research and acknowledge and incorporate the complex social ecological situation which constrained or enabled action for the species. In so doing we moved beyond the traditional sphere of an applied ecologist-a move which was both challenging and rewarding. Calling on theoretical perspectives beyond the accepted space gave our work credibility and focus as it empowered and motivated us to not only undertake rigorous ecological research, but also: to act and advocate; reflect and confront the internal and external constraints to our work; incorporate the interdisciplinary approaches necessary for understanding and responding to the complex context (and immediate threat) which Sloane's Froglet was connected to; and, express, reflect upon and harness our care for the biosphere.

Bammer et al. (2020) consider scientific fragmentation as antithetical to the development of integrated and integrating knowledges needed to address complex issues. They suggest one driver of fragmentation is the 'tribal' behaviour of scientists, where shared words, customs and expectations positively reinforce inward looking behaviours and rewards. Intentional ecology may assist with undermining tribalism. We found that intentionally advocating caring for the environment provided a legitimate, active space for members of specialist tribes (frog ecologists, water ecologists, vegetation experts, management scientists, experienced citizens) to open up, rather than hunker down, as a shared purpose was clearly articulated.

While acknowledging their care for the environment, many researchers may find an overt expression of care confronting or even dangerous. Can values and emotion assist in scientific enquiry? Emotions which are understood within a framework of a soundly based environmental ethic such as Wilson's (1984) biophilia can assist in research. They can push researchers to be careful with survey design, to think closely about the methods being used; to act with intention and purpose. Particularly where feelings and the ethics are explicit, recorded, and considered, in a theoretical framework provided by environmental philosophy, they provide a foundation that drives researchers to produce better work. Latour (1998, p. 208) gives some perspective on this when he writes "Science is certainty; research is uncertainty. Science is supposed to be cold, straight, and detached; research is warm, involving, and risky. Science puts an end to the vagaries of human disputes; research creates controversies. Science produces objectivity by escaping as much as possible from the shackles of ideology, passions, and emotions; research feeds on all of those to render objects of enquiry familiar". In addition, we found that our enthusiasm for Sloane's Froglet (a rather small and non-descript species) inspired others in a way that a mere description of facts did not.

Our approach, with its emphasis on multiple methods and acting for improvement, necessitated interdisciplinary and transdisciplinary research. Transdisciplinary studies and integrating research are usually situated within a collaborative framework, where ecologists and social scientists work together (Clark and Stankey 2006). Understanding wicked issues also necessitates the development of transdisciplinary studies (West et al., 2019; Roux et al., 2017). Ryder et al. (2010) suggest that many players from different disciplines and with different types of knowledge are needed to address wicked issues and the approach is invariably controversial (p. 825). In the case of collaborative research, Pooley et al. (2014) affirm that "all researchers should consider the shaping effects of their personal and disciplinary values, motivations, and conceptual frameworks" (p. 29). In a recent case specifically related to amphibians, Calhoun et al. (2014) demonstrate the importance of "interdisciplinary and engaged" (p. 11005) research, and promote interdisciplinary research as useful in developing "novel mechanisms for conservation" (Calhoun et al., 2014, p. 11005).

Despite acknowledgement of the need for interdisciplinary approaches, participatory processes which aspire to respond to sustainability issues often ignore political differences between actors, whether they be scientists or practitioners. Turnhout et al. (2020) consider the lack of success of current knowledge coproduction and participatory processes as in part due to unequal power relations between participants which privilege scientific knowledge. The intentional ecology framework requires open reflection and exploration of values, the explicit acknowledgement of boundaries and a recognition of intent which may help counter this privilege. When incorporated into a collaborative reflexive process to transformation (Borie et al., 2020), an intentional ecology approach could help in recognising and accepting difference, while working towards a multifaceted outcome.

The interdisciplinary process we undertook was not without heartache. Eigenbrode et al. (2007) notes that integrated research raises "conceptual and methodological challenges" that are disparate and difficult (p. 55). As Norgaard (2008) points out, and Ostrom in her discussion of social ecological systems reiterates, "the ecological and social sciences have developed independently and do not combine easily" (Ostrom, 2009, p. 419). We greatly appreciated the assistance of associates with a wide range of research foundations and approaches and acknowledge the benefit of using a collaborative team when crossing boundaries and gathering and mobilising processes from different disciplines. Despite the difficulties, the transdisciplinary approach has been both exciting and illuminating and, we believe, is essential for addressing the ongoing challenges facing environmental research and practice.

If this project had been a more conventional study the results would be published in the research thesis (Knight, 2015), and eventually in academic journals. Policy makers, planners, land and water managers and local residents would have limited knowledge of the presence of Sloane's Froglet and limited access to the new information available about Sloane's Froglet, even if they were seeking such information. Advocacy for Sloane's Froglet and collaboration with environmental practitioners when undertaking the research have led to beneficial actions being undertaken for the species in particular situations and ongoing 
action by previously uninvolved individuals and groups to undertake creative and restorative projects to conserve Sloane's Froglet. The Sloane's Froglet case has developed a life of its own, outside of our work.

The intentional ecology conceptual framework used in the Sloane's Froglet case assisted in developing a research programme that is richer for its representativeness of the complex space in which Sloane's Froglet is situated. In this case, in particular, the early awareness of the context of Sloane's Froglet distribution contributed to urgency for action. The feeling of care for this small species has been shared with the community and motivated them to learn about and act with care for Sloane's Froglet. Knowledge exchange and advocacy early in the development of the research have had beneficial outcomes for Sloane's Froglet. Local conservation organisations became aware of the situation of Sloane's Froglet quickly after knowledge was shared. Environmental champions also began to take action and share knowledge to benefit Sloane's Froglet. These individuals and organisations also supported the research team. Individual sites were protected even as new knowledge was being created. While an adaptive management approach to looking after this species has not yet been fully instigated, knowledge of the species and its habitat needs has been mobilised and entered a 'mainstream' realm where it is considered in institutional processes. Most importantly, the new ecological knowledge has not emerged alone, in peril of becoming a fad, but into a community that is partially knowledgeable and so partially skilled to act for Sloane's Froglet.

Applied, conservation and translational ecologists, as well as action-oriented and intervention-focussed researchers (van Kerkhoff and Pilbeam, 2017) are all faced with the difficulty of either providing their new knowledge through the established academic framework of peer-reviewed publications which can be slow to appear and are often not read or acted upon by practitioners, or seeking another way to exchange and ensure the utilisation of their knowledge. Concerns with stepping over the line from researcher to activist abound, as do concerns with the inaction of policy-makers or practitioners when provided with new knowledge (e.g. Martin et al., 2012; van Herten and Runhaar, 2013).

Ultimately the intentional ecology framework provides a guide for discussion and practice. There is potential to apply an intentional ecology approach to many current biodiversity and sustainability challenges. While the Sloane's Froglets case may appear to be small, contained and even simple with its focus on a single species, it has many characteristics of the larger difficulties that researchers and practitioners face including: disbelief in the face of new knowledge; vested interests with large sums of money discrediting science and scientists; the mischievous spread of misinformation; the need to change policy and law; and, a lack of funding for more research and action.

In these circumstances, the benefit of having a framework that pushes researchers to consider the research boundaries and how their values affect them; to reflect upon what research and advocacy actions to take; and, which drives us to consider and incorporate disparate methodologies can be great when trying to ensure new knowledge is used. The application of an intentional ecology framework can facilitate transdisciplinary studies which deliver applied research in a complex context. The framework can also act as a focus for scaling out or scaling up from local initiatives, as it provides a direct link from science to policy via moral questions of what should be done.

By operating with this framework researchers develop expertise in very different methodologies and reflect upon the strengths of them all. Researchers have a solid frame in which to explore ideas that might otherwise seem unbounded. For the passionate frog researcher (or ornithologist, or ichthyologist, or, etc.), with their strong care for the natural world, an intentional ecology provides a theoretical framework in which attempts to act and advocate based on increasing knowledge do not reduce credibility. Care for the species can be understood as an ethic and motivating force without limiting researchers' ability to present sound evidence. Most importantly, an intentional ecology provides a platform and imperative for choice and action. We believe this approach provides a foundation for understanding the complexities of the social ecological context in which research and practice meet and motivation for applying that understanding. As such, it provides hope for a continued complex, dynamic, diverse and beautiful world.

Received: 31 May 2021; Accepted: 26 October 2021; Published online: 23 November 2021

\section{References}

Allan C (2009) Reviewing adaptive management through a wicked lens. In: Lane $\mathrm{CR}$, Taylor BD (eds) Contested Country: local and regional natural resources management in Australia. CSIRO, Brisbane, pp. 215-226

Anstis M (2002) Tadpoles of South-eastern Australia: a guide with keys. Reed New Holland, Sydney

Anstis M (2013) Tadpoles and frogs of Australia. New Holland Publishers, London Bammer G, O’Rourke M, O'Connell D et al. (2020) Expertise in research integration and implementation for tackling complex problems: when is it needed, where can it be found and how can it be strengthened? Palgrave Commun 6(1):5. https://doi.org/10.1057/s41599-019-0380-0

Borie M, Gustafsson KM, Obermeister N et al. (2020) Institutionalising reflexivity? Transformative learning and the Intergovernmental science-policy Platform on Biodiversity and Ecosystem Services (IPBES). Environ Sci Policy 110:71-76

Calhoun AJK, Jansujwicz JS, Bell KP, Hunter Jr ML (2014) Improving management of small natural features on private lands by negotiating the science-policy boundary for Maine vernal pools. Proc Natl Acad Sci USA 111:11002-11006

Ceballos G, Ehrlich PR, Barnosky AD et al. (2015) Accelerated modern humaninduced species losses: entering the sixth mass extinction. Sci Adv 1(5) https://doi.org/10.1126/sciadv.1400253

Clark RN, Stankey G (2006) Integrated research in natural resources: the key role of problem framing. General technical report PNW-GTR-678. Forest Service Pacific Northwest Research Station: USDA

Cullen P (2004) Turning the tide: how does science change public policy? Paper presented at CSIRO land and Water Seminar World Water Day Address; 22 March 2004, Adelaide. http://www.wentworthgroup.org/docs/Turning_the_Tide.pdf

Cullen P (2006) Science and politics—speaking truth to power. Paper presented at North American Benthological Society Annual Conference, June 2006, Anchorage, Alaska, USA.

Department of Agriculture, Water and the Environment (2019) Amendments to the EPBC Act list of threatened species and ecological communities https:// www.environment.gov.au/news/2019/06/28/amendments-epbc-act-listthreatened-species-and-ecological-communities Accessed 18 Dec 2020

Eigenbrode SD, O'Rourke M, Wulfhorst JD et al. (2007) Employing philosophical dialogue in collaborative science. BioScience 57(1):55-64. https://doi.org/ 10.1641/b570109

Enquist CAF, Jackson ST, Garfin GM et al. (2017) Foundations of translational ecology. Front Ecol Environ 15(10):541-50. https://doi.org/10.1002/fee.1733

Fazey I, Evely AC, Reed MS et al. (2013) Knowledge exchange: a review and research agenda for environmental management. Environ Conserv 40:19-36. https://doi.org/10.1017/S037689291200029X

Fazey I, Schäpke N, Caniglia G et al. (2018) Ten essentials for action-oriented and second order energy transitions, transformations and climate change research. Energy Res Soc Sci 40:54-70. https://doi.org/10.1016/j.erss.2017.11.026

Gardner TA, Barlow J, Peres CA (2007) Paradox, presumption and pitfalls in conservation biology: the importance of habitat change for amphibians and reptiles. Biol Conserv 138:166-179. https://doi.org/10.1016/j.biocon.2007.04.017

Garrard GE, Fidler F, Wintle BC et al. (2016) Beyond advocacy: making space for conservation scientists in public debate. Conserv Lett 9:208-212. https:// doi.org/10.1111/conl.12193

Gorman TA, Haas CA (2011) Seasonal microhabitat selection and use of syntopic populations of Lithobates okaloosae and Lithobates clamitans clamitans. J Herpetol 45:313-318. https://doi.org/10.1670/10-135.1

Hay P (2008) Science, ethics and emotion in the politics of biodiversity. In: Lefroy $\mathrm{T}$, Bailey K, Norton T (eds) Biodiversity: integrating conservation and production. CSIRO Publishing, Collingwood, pp. 3-12

Hero J-M, Morrison C, Gillespie GR, Roberts JD, Newell D, Meyer E et al. (2006) Overview of the conservation status of Australian frogs. Pac Conserv Biol 12:319-380. https://doi.org/10.1071/PC060313 
Holling CS (1978) Adaptive environmental assessment and management. Wiley, Chichester

Hughes L (2008) Sloane's Froglet Crinia sloanei-vulnerable species listing. https:// www.environment.nsw.gov.au/topics/animals-and-plants/threatened-species/ nsw-threatened-species-scientific-committee/determinations/finaldeterminations/2008-2010/sloanes-froglet-crinia-sloanei-vulnerable-specieslisting Accessed 18 Dec 2020

Johnston D (2017) 3.5 hectares set aside for Sloane's froglet habitat within Thurgoona residential estate. Bord Mail http://www.bordermail.com.au/story/ 4640539/froglet-on-end-of-some-estate-love/ Accessed 18 Dec 2020

Knight AR (2013a) The distribution of Sloane's Froglet, Crinia sloanei, in southern NSW and northern Victoria: a review of historical distribution records and results from surveys undertaken from 2010 to 2013. Report number 70 . Institute of Land, Water and Society, Albury

Knight AR (2013b) Sloane's froglet, crinia sloanei. Albury Conservation Company, Albury

Knight AR (2014) Sloane's Froglet interim habitat guide and management recommendations. https://www.alburyconservationco.org.au/wp-content/ uploads/2015/02/Sloanes-Froglet_Office-of-Enviroment-Herritage-A5Booklet-A4_reduced-size.pdf Accessed 18 Dec 2020

Knight AR (2015) The case for Sloane's Froglet: generating ecological knowledge with the intent to benefit biodiversity. PhD dissertation, Charles Sturt University, Australia

Lach D, List P, Steel B, Shindler B (2003) Advocacy and credibility of ecological scientists in resource decisionmaking: a regional study. BioScience 53:170-178. 10.1641/0006-3568(2003)053[0170:AACOES]2.0.CO;2

Latour B (1998) From the world of science to the world of research? Science 280:208-209. https://doi.org/10.1126/science.280.5361.208

Lauck B (2005) The impact of recent logging and pond isolation on pond colonization by the frog Crinia signifera. Pac Conserv Biol 11:50-56. https:// doi.org/10.1071/PC050050

Lemckert F (2001) The influence of micrometeorological factors on the calling activity of the frog Crinia signifera (Anura: Myobatrachidae). Aust Zool 31:625-631. https://doi.org/10.7882/AZ.2001.009

Leopold A (1949) A Sand County Almanac: and sketches here and there. Oxford University Press, New York

Letnic M, Fox BJ (1997) The impact of industrial fluoride fallout on faunal succession following sand-mining of dry sclerophyll forest at Tomago, NSW, II. Myobatrachid frog recolonization. Biol Conserv 82:137-146

Levy N (2013) Toward a new environmental ethic in contemporary feminist theory. Hecate $38: 9-23$

Littlejohn MJ (1958) A new species of frog of the genus Crinia Tschudi from South-eastern Australia. Proc Linn Soc N S W 83:222-226

Littlejohn MJ (1964) Geographic isolation and mating call differentiation in Crinia signifera. Evolution 18:262-266

Longino HE (1987) Can there be a feminist science? Hypatia 2:51-64

Lovejoy TE (2009) Introduction. In: Collins JP, Crump ML, Lovejoy TE (eds) Extinction in our times: global amphibian decline. Oxford University Press, Oxford, pp. xi-xiv

Marder MP (2011) Research methods for science. Cambridge University Press, Cambridge

Martin TG, Nally S, Burbidge AA et al. (2012) Acting fast helps avoid extinction. Conserv Biol 5:274-280. https://doi.org/10.1111/j.1755-263X.2012.00239.x

Meine C, Soule M, Noss RF (2006) "A mission-driven discipline": the growth of conservation biology. Conserv Biol 20:631-651. https://doi.org/10.1111/ j.1523-1739.2006.00449.x

Meyer EA, Hines HB, Clarke JM et al. (2004) Occurrence of the Wallum Froglet (Crinia tinnula) at Littabella National Park, southeastern Queensland. Memoirs Queensland Museum 49:691-692

Midgley G (2003) Science as systemic intervention: some implications of systems thinking and complexity for the philosophy of science. Syst Pract Action Res 16:77-97. https://doi.org/10.1023/A:1022833409353

Minteer B, Collins J (2008) From environmental to ecological ethics: toward a practical ethics for ecologists and conservationists. Sci Eng Eth 14:483-501. https://doi.org/10.1007/s11948-008-9087-0

Nelson MP, Vucetich JA (2009) On advocacy by environmental scientists: what, whether, why, and how. Conserv Biol 23:1090-1101. https://doi.org/10.1111/ j.1523-1739.2009.01250.x

Norgaard RB (2008) Finding hope in the millennium ecosystem assessment. Conserv Biol 22:862-869. https://doi.org/10.1111/j.1523-1739.2008.00922.x

Nowotny H, Scott P, Gibbons M (2001) Re-thinking science. Knowledge and the public in an age of uncertainty. Polity Press, Cambridge

Ostrom E (2009) A general framework for analyzing sustainability of social-ecological systems. Science 325:419-422. https://doi.org/10.1126/science.1172133

Partenza N (2010) Endangered frogs on the border. Bord Mail. http:// www.bordermail.com.au/story/54202/endangered-frogs-on-the-border/ Accessed 18 Dec 2020
Pooley SP, Mendelsohn JA, Milner-Gulland EJ (2014) Hunting down the chimera of multiple disciplinarity in conservation science. Conserv Biol 28:22-32. https://doi.org/10.1111/cobi.12183

Popescu VD, Kissel AM, Pearson M et al. (2013) Defining conservation-relevant habitat selection by the highly imperiled Oregon Spotted Frog, Rana pretiosa. Herpetol Conserv Biol 8:688-706

Raymond CM, Fazey I, Reed MS et al. (2010) Integrating local and scientific knowledge for environmental management. J Environ Manag 91:1766-1777. https://doi.org/10.1016/j.jenvman.2010.03.023

Read K, Keogh JS, Scott IA et al. (2001) Molecular phylogeny of the Australian frog genera Crinia, Geocrinia, and allied taxa (Anura: Myobatrachidae). Mol Phylogenet Evol 21:294-308. https://doi.org/10.1006/mpev.2001.1014

Reiners DS, Reiners WA, Lockwood JA (2013) The relationship between environmental advocacy, values, and science: a survey of ecological scientists attitudes. Ecol Appl 23:1226-1242. https://doi.org/10.1890/12-1695.1

Roux DJ, Nel JL, Cundill G et al. (2017) Transdisciplinary research for systemic change: who to learn with, what to learn about and how to learn. Sustain Sci 12(5):711-726. https://doi.org/10.1007/s11625-017-0446-0

Ryder DS, Tomlinson M, Gawne B, Likens GE (2010) Defining and using 'best available science': a policy conundrum for the management of aquatic ecosystems. Mar Freshw Res 61:821-828. https://doi.org/10.1071/MF10113

Schuttenberg HZ, Guth HK (2015) Seeking our shared wisdom: a framework for understanding knowledge coproduction and coproductive capacities. Ecol Soc 20 https://doi.org/10.5751/ES-07038-200115

Simpkins CA, Shuker JD, Lollback GW et al. (2014) Environmental variables associated with the distribution and occupancy of habitat specialist tadpoles in naturally acidic, oligotrophic waterbodies. Austral Ecol 39:95-105. https:// doi.org/10.1111/aec. 12048

Society for Conservation Biology (2020) Beliefs. Society for Conservation Biology, a globalized approach. https://conbio.org/about-scb/who-we-are/\#values Accessed 22 Dec 2020

Soulé ME (1985) What is conservation biology? BioScience 35:727-734

Stephens A (2012) Feminist systems theory: learning by praxis. Syst Pract Action Res 25:1-14. https://doi.org/10.1007/s11213-011-9212-x

Subramaniam B (2009) Moored metamorphoses: a retrospective Essay on Feminist Science Studies. Signs 34:951-980

Turnhout E, Metze T, Wyborn C et al. (2020) The politics of co-production: participation, power, and transformation. Curr Opin Environ Sustain 42:15-21. https://doi.org/10.1016/j.cosust.2019.11.009

Turnhout E (2018) The politics of environmental knowledge. Conserv Soc 16:363-371

van Herten ML, Runhaar HAC (2013) Dialogues of the deaf in Dutch eel management policy. Explaining controversy and deadlock with argumentative discourse analysis. J Environ Plan Manag 56:1002-1020. https://doi.org/ $10.1080 / 09640568.2012 .715083$

van Kerkhoff L, Pilbeam V (2017) Understanding socio-cultural dimensions of environmental decision-making: a knowledge governance approach. Environ Sci Policy 73:29-37. https://doi.org/10.1016/j.envsci.2017.03.011

von Wright G (1971) Explanation and understanding. Routledge and Kegan Paul, London

West S, van Kerhoff L, Wagenaar H (2019) Beyond "linking" knowledge and action: towards a practice-based approach to transdisciplinary sustainability interventions. Policy Stud 40(5):534-555. https://doi.org/10.1080/ 01442872.2019 .1618810

Wilson EO (1984) Biophilia. Harvard University Press, Cambridge

Wittemyer G, Berger J, Crooks KR, Noon BR, Pejchar L, Reed SE, Savidge JA (2018) To advocate or not is no longer the question: paths to enhance scientific engagement. BioScience 68:13-14

Woinarski JCZ, Burbidge AA, Harrison PL (2015) Ongoing unraveling of a continental fauna: decline and extinction of Australian mammals since European settlement. Proc Natl Acad Sci USA 112:4531-4540. https://doi.org/10.1073/ pnas. 1417301112

Zscheischler J, Rogga S (2015) Transdisciplinarity in land use science-a review of concepts, empirical findings and current practices. Futures 65:28-44. https:// doi.org/10.1016/j.futures.2014.11.005

\section{Acknowledgements}

We thank Natasha Lappin for providing a significant contribution to the conservation of Sloane's Froglet and the ideas in this work. We thank the landholders who provided access to their wetlands, the participants who contributed to an understanding of knowledge exchange processes and those that undertook actions to protect Sloane's Froglet. Professor Robyn Watts and Dr. David Hunter provided expert guidance in some aspects of the research. This work was funded by an Australian Postgraduate Research Award from the Australian Government and with additional financial and moral support from the Albury Conservation Company. 


\section{Ethical approval}

The work presented in this paper was part of a larger research project which was undertaken with approval from Charles Sturt University Human Research Ethics Committee, approval number 2014/029, and Charles Sturt University Animal Care and Ethics Committee, approval number 10/053. The procedures used in this study adhere to the tenets of the Declaration of Helsinki.

\section{Informed consent}

All research was carried out in accordance with the relevant approvals and regulations, including obtaining informed consent for any contributions from human participants.

\section{Competing interests}

The authors declare no competing interests.

\section{Additional information}

Correspondence and requests for materials should be addressed to Alexandra R. Knight.

Reprints and permission information is available at http://www.nature.com/reprints
Publisher's note Springer Nature remains neutral with regard to jurisdictional claims in published maps and institutional affiliations.

\section{(c) (i)}

Open Access This article is licensed under a Creative Commons Attribution 4.0 International License, which permits use, sharing, adaptation, distribution and reproduction in any medium or format, as long as you give appropriate credit to the original author(s) and the source, provide a link to the Creative Commons license, and indicate if changes were made. The images or other third party material in this article are included in the article's Creative Commons license, unless indicated otherwise in a credit line to the material. If material is not included in the article's Creative Commons license and your intended use is not permitted by statutory regulation or exceeds the permitted use, you will need to obtain permission directly from the copyright holder. To view a copy of this license, visit http://creativecommons.org/ licenses/by/4.0/.

(C) The Author(s) 2021 